\title{
Influence of loading level on the bearing capacity of RC columns strengthened by jacketing
}

\author{
Pavlo Krainskyi ${ }^{1}$, Yaroslav Blikharskyy ${ }^{2,}$, Roman $^{*}$ Khmil $^{1}$ and Pavlo Vegera ${ }^{1}$ \\ ${ }^{1}$ Lviv Polytechnic National University, Department of Building Constructions and Bridges, 79013, \\ 6, Karpinskogo str., Lviv, Ukraine \\ ${ }^{2}$ Lviv Polytechnic National University, Department of Highways and Bridges, 79013, \\ 6, Karpinskogo str., Lviv, Ukraine
}

\begin{abstract}
Compressed reinforced concrete elements are quite common in construction. An example of such elements is the columns of industrial buildings, which are loaded with eccentric force, for example, from a bridge crane, columns of multistory buildings, structures subjected to compression and bending. When the reinforced concrete structure becomes unfit to future operation, it is often more economical and easy to retrofit it than to change it for a new one. Most of these structures are influenced by certain loads and unloading the structures before strengthening is not always possible. Therefore, in this work reinforced concrete structures strengthened by jacketing are investigated. To simulate the real life conditions, the loading level of $65-70 \%$ of the not strengthened column bearing capacity was maintained during jacketing. This load level simulates the actual service load on the structure. The bearing capacity load and serviceability limit state of not strengthened and jacketed reinforced concrete columns were investigated and the experimental results are presented in this paper.
\end{abstract}

\section{Introduction}

Reinforced concrete is a widespread material in construction. In structural elements, subjected to compression with bending, compressive stresses are taken by concrete while tensile stresses are transmitted to the rebar. At the same time, concrete serves as protection of structures from corrosion and various damages.

Many works are devoted to the use of improved high-strength concrete in reinforced concrete structures $[1,2]$. In particular the investigations of special mineral additives like zeolite should be noted, which improve durability and corrosion resistance of cements [3].

Since most of the reinforced concrete structures in operation are made of traditional concrete, the issue of extending their serviceability time is relevant.

Many factors cause necessity for repairing or strengthening of buildings and constructions. Often it is corrosion or damages of construction $[4,5]$ during its lifetime

\footnotetext{
${ }^{*}$ Corresponding author: yaroslav.z.blikharskyy@lpnu.ua
} 
from adverse environment influence. Also, it is new requirements for design, through changing of the functional purpose, installation of new equipment, upgrading engineering networks, improving architectural qualities of the building.

There are some new methods of strengthening RC constructions [6]. Reinforced concrete jacketing is one of the traditional and common methods of $\mathrm{RC}$ structures strengthening [7]. RC jacketing can be applied to both flexural and compressed members and has some significant advantages. One of the important in $\mathrm{RC}$ jacketing is the bond between repair materials and concrete substrate [8]. Jacketed member usually do not need additional corrosion or fire protection. But in jacketing need to provide shear strength or reinforce them too [9].

Many studies have been carried out to determine the stress-strain state of the jacketed RC members [10-13], bonding and surface preparation influence on the performance of jacketed structure [14] and seismic retrofitting using RC jacketing $[15,16]$.

Nevertheless, further study of this type of strengthening is relevant, since little is known about the performance of the structures strengthened under loads of different magnitude. The goal of this work to check the strengthening and serviceability effect of columns strengthened without and with initial load as $65-70 \%$ of C-1 and C-2 reference columns load-bearing capacity.

\section{Research methodology}

\subsection{Test specimen description and material properties}

All specimens were tested as pinned columns on a compression test stand (Fig. 1). This stand was designed to conduct compression tests in horizontal position which makes it more convenient to read data from mechanical gauges. Eccentrically loaded for every column eccentricity was $150 \mathrm{~mm}$. Load to the columns was applied incrementally by hydraulic jack. Loading level was determined from the readings of a ring dynamometer.

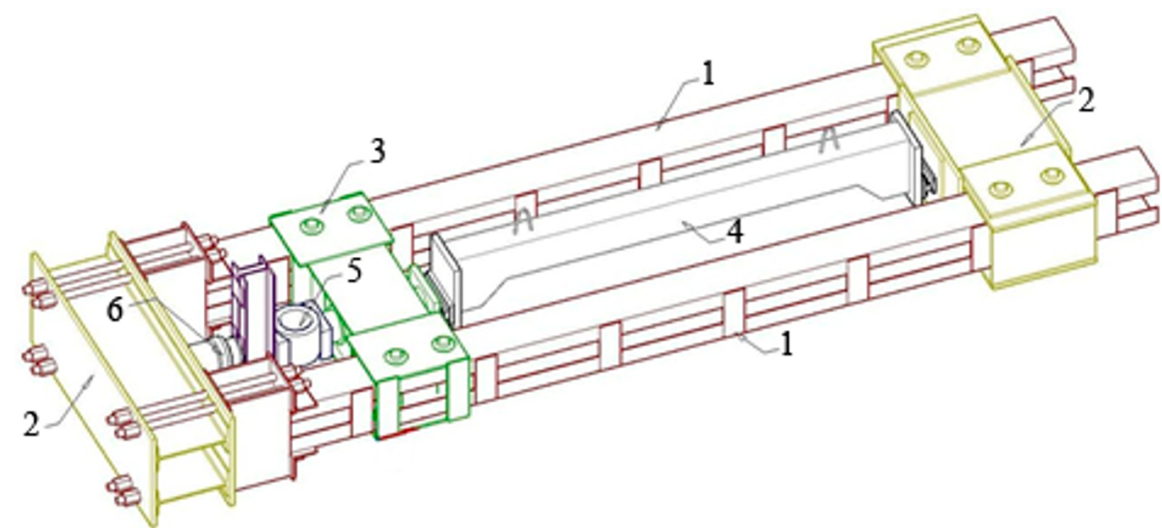

Fig. 1. Stand for columns compression test (1- steel constructions of stand; 2- rigid steel beam; 3rigid steel beam with plunger; 4- tested column; 5- ring dynamometer; 6 - hydraulic jack).

The length of the columns was $2.2 \mathrm{~m}$ and a cross section dimensions before jacketing was $0.14 \times 0.18 \mathrm{~m}$. Columns were tested as compressed-bent elements and were manufactured with corbels on both ends for that purpose. Cross-section dimensions of the jacketed columns were increased to $0.2 \times 0.26 \mathrm{~m}$. All six columns were manufactured from the same materials. Material specimens were selected and tested to determine the mechanical properties. For cross section dimensions and reinforcement details see 
Fig. 2 a, b. Reinforcement ratio of not strengthened column was $1.8 \%$. Four $12 \mathrm{~mm}$ rebar were used as longitudinal reinforcement with $6 \mathrm{~mm}$ rebar used for transverse reinforcement. The rupture stress of main rebar was $720 \mathrm{MPa}$; yield stress - $630 \mathrm{MPa}$; Young's modulus $210 \mathrm{GPa}$. The test of rebar's were made as in [17]. Average concrete cube strength was $37 \mathrm{MPa}$, which corresponds to C25/30 concrete class.

Reinforced concrete jacketing length was $1.7 \mathrm{~m}$, reinforcement ratio was $1.17 \%$. Four $10 \mathrm{~mm}$ rebar were used as jacketing longitudinal reinforcement (Fig 2, 3) with $6 \mathrm{~mm}$ rebar used for ties. Mechanical properties of concrete and rebar were the same as previous. The preparation of the concrete surface before jacketing consisted only from dust removal and sample hydration.

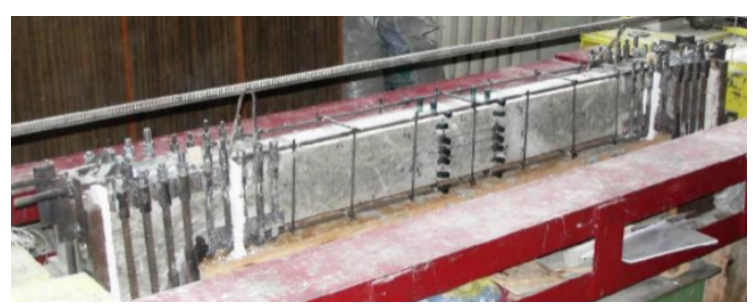

Fig.2. Reinforcement details of strengthened column specimen.

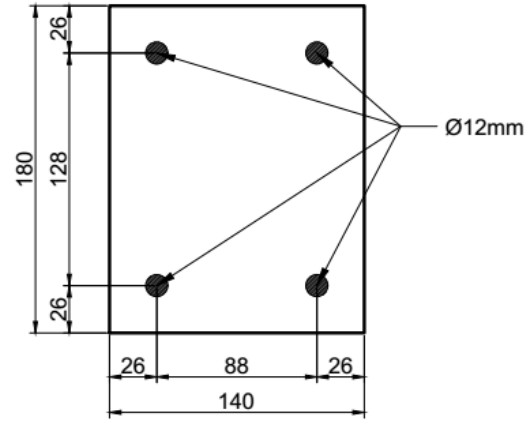

a)

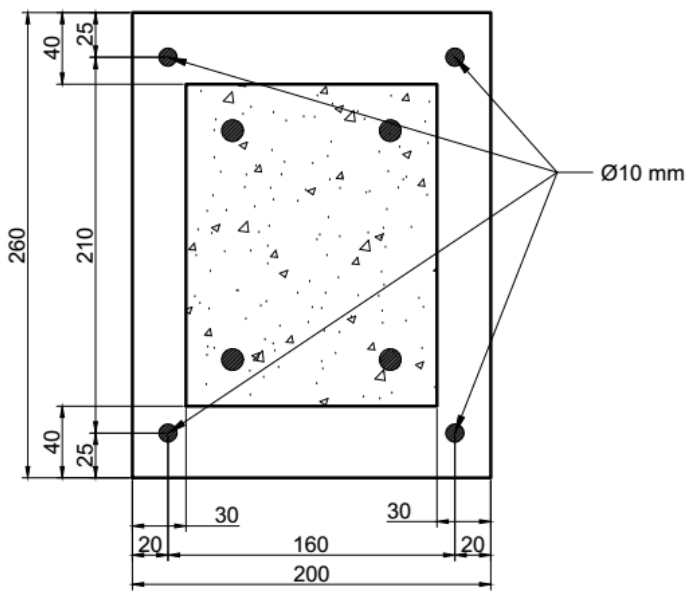

b)

Fig.3. Cross section dimensions and reinforcement details of unstrengthened (a) and strengthened (b) specimen's.

\subsection{Experimental program}

The first two columns C-1 and C-2 were reference columns. They were tested without strengthening to determine the bearing capacity of the specimen and to adopt the service load value for the next tests.

Columns C-3-0 and C-4-0 were also reference columns. They were tested after strengthening but without any initial load. The load-bearing capacity of these specimens was considered as maximum possible and was used for comparison of the strengthening effect of the following jacketed columns. 
Columns C-5-0.7 and C-6-0.7 were initially loaded to a service load which was adopted as $65-70 \%$ of $\mathrm{C}-1$ and $\mathrm{C}-2$ reference columns load-bearing capacity. Afterwards, they were strengthened and tested to failure.

Columns were tested with pinned supports. Load was applied incrementally as a force on one of the supports. The following data was acquired during the tests of the columns: strain in the rebar; strain on the compressed face of the concrete; deflection of the midheight of the column.

\section{Results of the experimental study}

All columns failed in a flexural manner at midsection. In case of columns C-01 and C-02 bearing-capacity was exceeded after column's tensioned reinforcement yielded, thus we consider the load when it happened a limit load. All strengthened specimens exceeded bearing-capacity after yielding of both column and jacketing reinforcement, which was accepted as a bearing-capacity load for the strengthened specimens.

Serviceability limit state allowed at load of maximum deflection. According to Ukrainian codes for serviceability limit state [18] the maximum deflection for test columns in this work $1 / 150$ from length. This value $14.7 \mathrm{~mm}$.

\subsection{C-1, C-2 reference columns}

C-1 and C-2 columns were tested to failure without strengthening. Specimens failed in flexural manner. Average load-bearing capacity of two specimens was $175 \mathrm{kN}$ (Fig. 4).

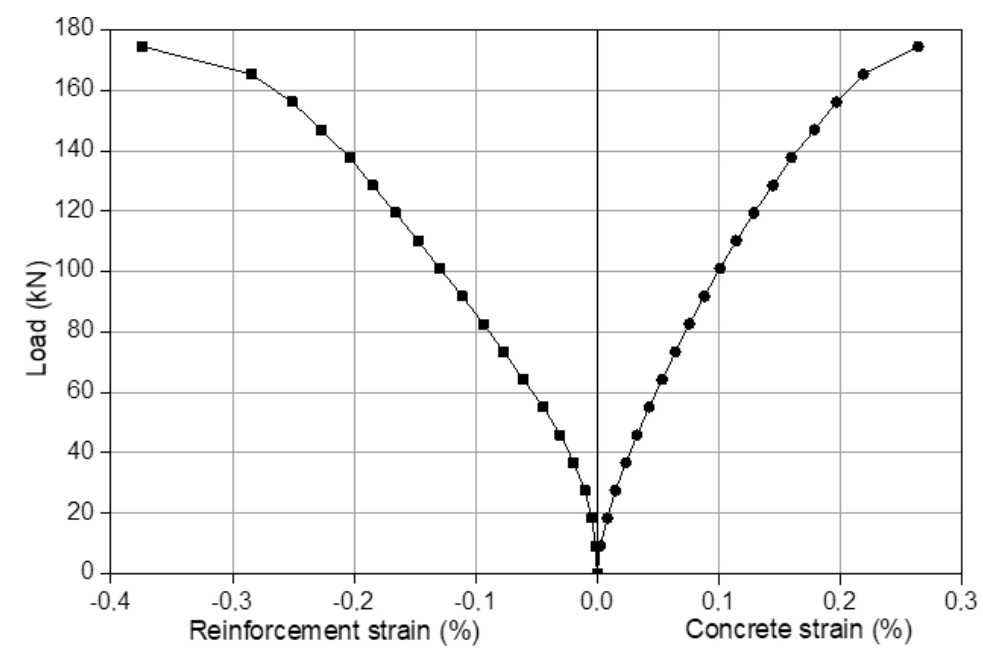

Fig. 4. Load vs reinforcement (concrete) strain for tested columns C-1 and C-2.

From Fig. 5 we can see that the loads that corresponded to a maximum allowed deflection of $14.7 \mathrm{~mm}$ were $122 \mathrm{kN}$ and $125 \mathrm{kN}$. 


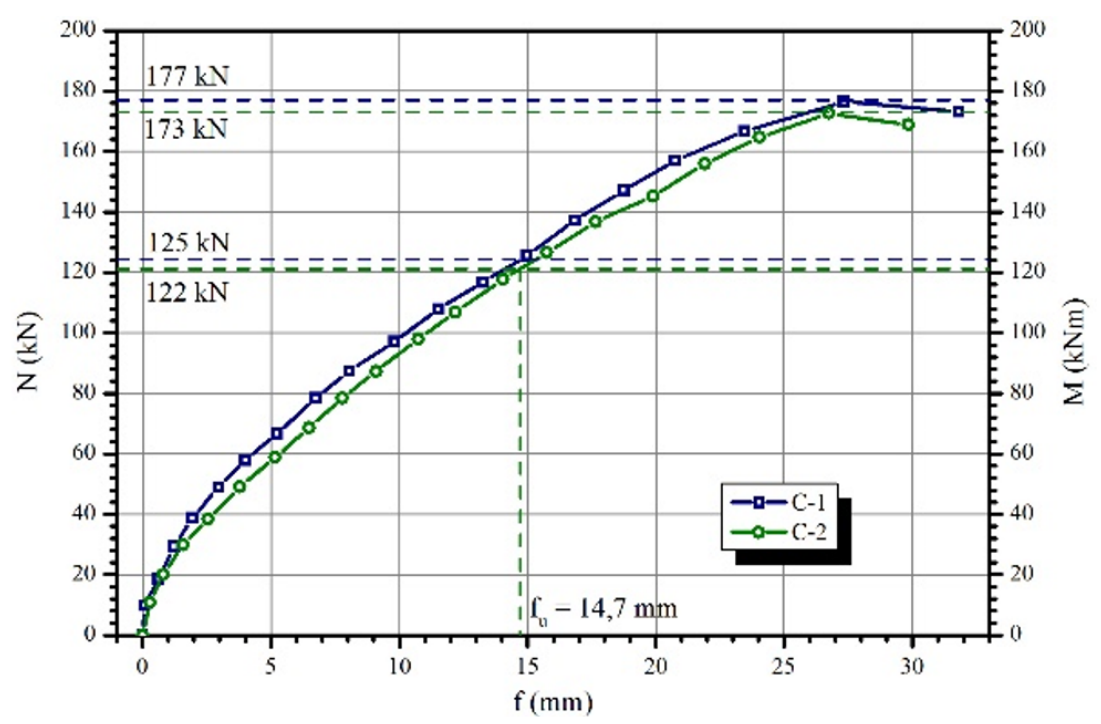

Fig. 5. C-1 and C-2 deflection at mid-height plot.

Considering these values we adopted a service loads for following tests of $123.5 \mathrm{kN}$.

\subsection{C-3-0, C-4-0 reference strengthened columns}

C-3-0 and C-4-0 columns were strengthened without initial loading and tested to failure. Specimens failed in flexural manner. Average load-bearing capacity of two specimens was $475 \mathrm{kN}$. It is 2.7 times bigger than the load-bearing capacity of C-1 and C-2 (see Fig. 6). It was consider it to be a maximum possible effect from strengthening since there were no initial stresses or deformations in the columns before strengthening.

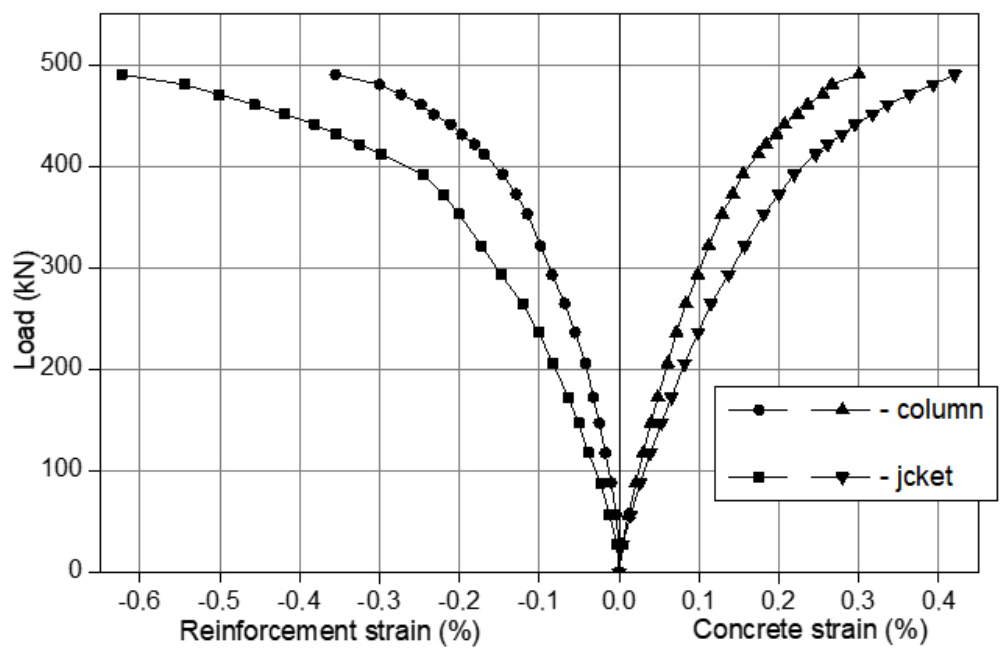

Fig. 6. Load vs reinforcement (concrete) strain for tested columns C-3-0 and C-4-0.

The load that corresponded to a maximum allowed deflection (Fig. 7) of $14.7 \mathrm{~mm}$ were $405 \mathrm{kN}$ and $380 \mathrm{kN}$. Considering these values we adopted a service loads for following tests of $392.5 \mathrm{kN}$. 


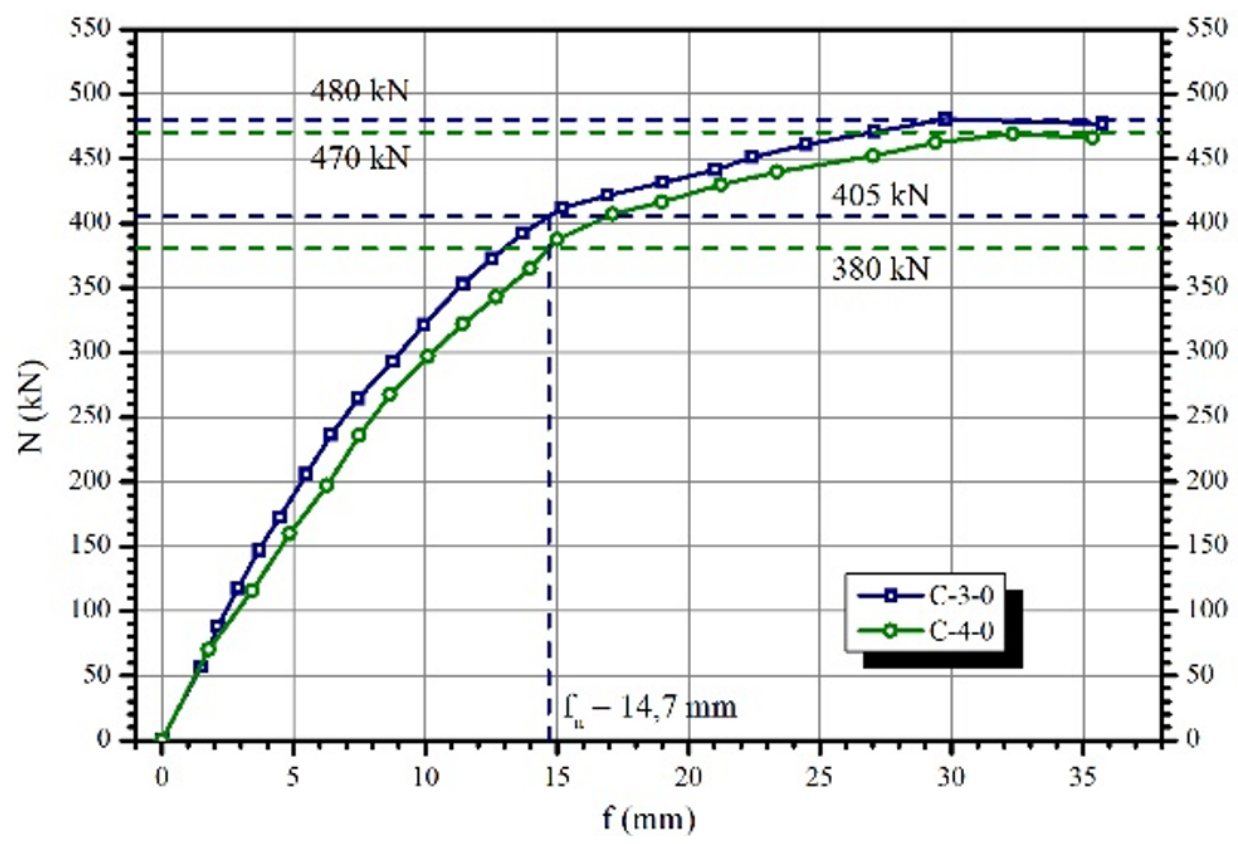

Fig.7. C-3-0 and C-4-0 deflection at mid-height plot.

\subsection{C-5-0.7, C-6-0.7 main strengthened columns}

C-5-0.7 and C-6-0.7 columns were initially loaded to a service load of $120 \mathrm{kN}$, strengthened and then tested to failure. Specimens failed in flexural manner. Average load-bearing capacity of two specimens was $430 \mathrm{kN}$. It is $90 \%$ of a maximum possible effect and 2.6 times bigger than the load-bearing capacity of C-1 and C-2 (see Fig. 8).

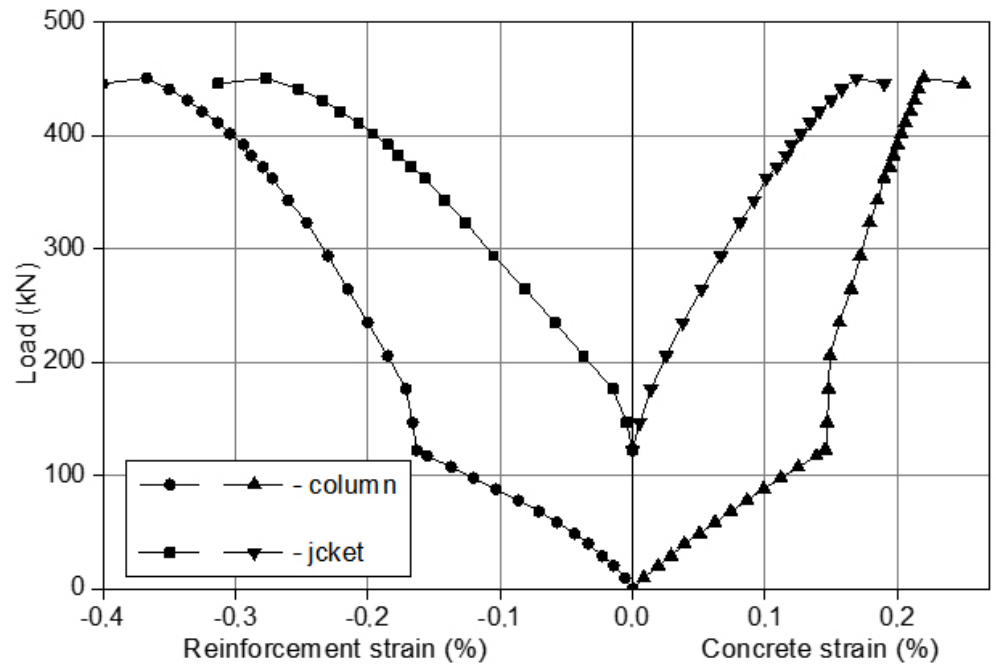

Fig. 8. Load vs reinforcement (concrete) strain for tested columns C-5-0.7 and C-6-0.7.

Although the application of the reinforced concrete jacketing was almost at the verge of exceeding the serviceability limit state requirements, some positive effect in deflection 
manner of the columns was still achieved. In Fig. 8 the increase in stiffness of the columns immediately after strengthening can be observed. This resulted in a very slow increase in deflections on first steps of loading after jacketing and 1.5 times increase in serviceability capacity.

The loads that corresponded to a maximum allowed deflection of $14.7 \mathrm{~mm}$ were $216 \mathrm{kN}$ and $167 \mathrm{kN}$ (Fig. 9). Considering these values we adopted a service loads for following tests of $191.5 \mathrm{kN}$.

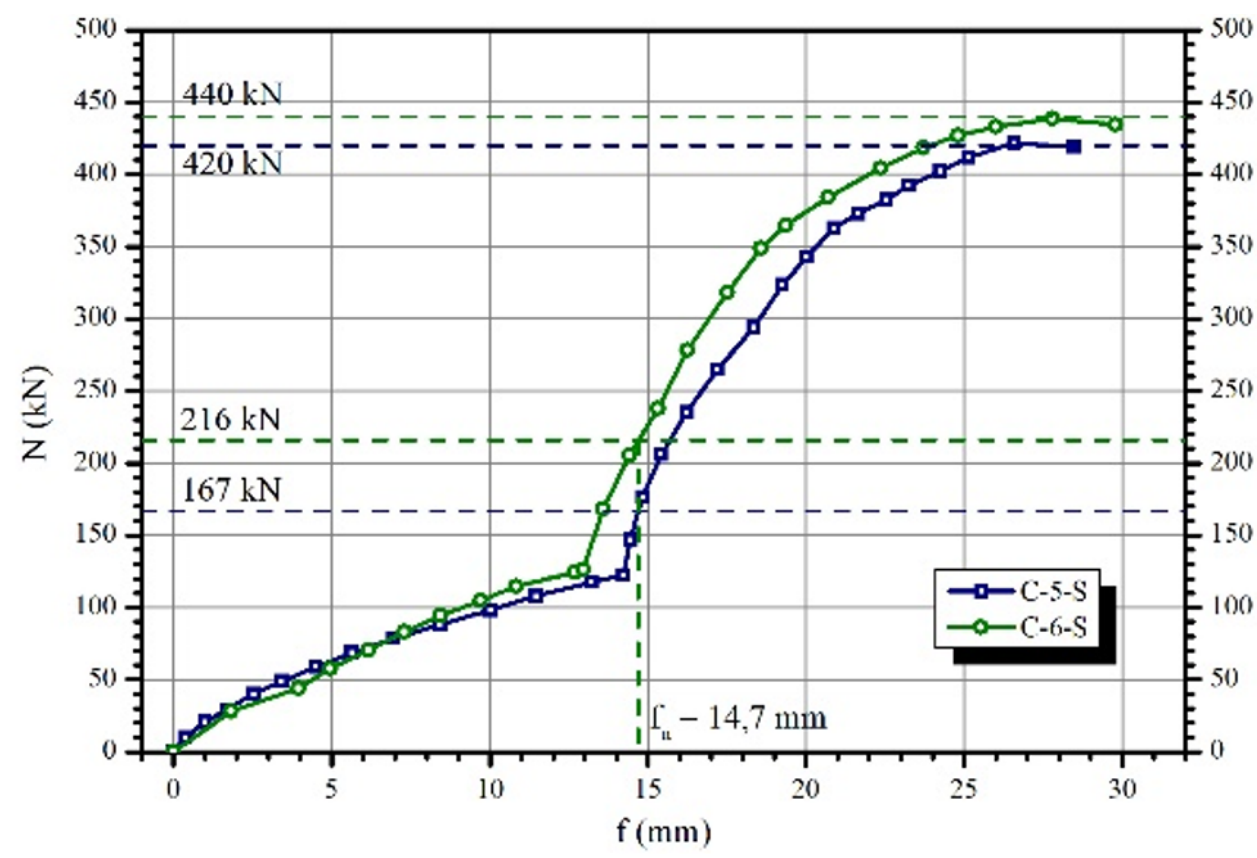

Fig.9. C-5-0.7 and C-6-0.7 deflection at mid-height plot.

For comparison of all samples the experimental data was summarized in Table1.

Table 1. Results of research.

\begin{tabular}{|c|c|c|c|c|c|c|c|c|}
\hline \multirow[t]{2}{*}{ Sample } & \multicolumn{2}{|c|}{$\begin{array}{l}\text { Load-bearing } \\
\text { capacity, kN }\end{array}$} & \multicolumn{2}{|c|}{$\begin{array}{l}\text { Strengthening } \\
\text { effect, } \%\end{array}$} & \multicolumn{2}{|c|}{$\begin{array}{l}\text { Load of max. } \\
\text { allowed } \\
\text { deflection, } k \mathrm{~N}\end{array}$} & \multicolumn{2}{|c|}{$\begin{array}{l}\text { Strengthening } \\
\text { effect, } \%\end{array}$} \\
\hline & sample & average & sample & average & sample & average & sample & average \\
\hline $\mathrm{C}-1$ & 177 & \multirow{2}{*}{175} & - & \multirow{2}{*}{ - } & 122 & \multirow{2}{*}{123.5} & - & \multirow{2}{*}{-} \\
\hline $\mathrm{C}-2$ & 173 & & - & & 125 & & - & \\
\hline C-3-0 & 480 & \multirow{2}{*}{475} & 175 & \multirow{2}{*}{172} & 405 & \multirow{2}{*}{392.5} & 228 & \multirow{2}{*}{218} \\
\hline C-4-0 & 470 & & 169 & & 380 & & 208 & \\
\hline C-5-0.7 & 420 & \multirow{2}{*}{430} & 142 & \multirow{2}{*}{146} & 216 & \multirow{2}{*}{191.5} & 75 & \multirow{2}{*}{55} \\
\hline C-6-0.7 & 440 & & 151 & & 167 & & 35 & \\
\hline
\end{tabular}

According to Table 1, the strengthening effect by load-bearing capacity for specimens C-3-0 and C-4-0 was 172\%, for specimens C-5-S and C-6-S - 146\%.

The strengthening effect by loading of maximum allowed deflection for specimens C-3-0 and C-4-0 was 218\%, for specimens C-5-0.7 and C-6-0.7 - 55\%. 
The strengthening effect decreases when the structure is under loading during strengthening that can be seen from the obtained test results.

\section{Conclusions}

After experimental research of reinforced concrete columns strengthened by RC jacket there was determined that strengthening effect can be achieved and depends on the presence or absence of the load during the strengthening:

1. the strengthening effect by load-bearing capacity for specimens C-3-0 and C-4-0 was $172 \%$, for specimens C-5-0.7 and C-6-0.7 - 146\%.

2. the strengthening effect by loading of maximum allowed deflection for specimens C-3-0 and C-4-0 was $218 \%$, for specimens C-5-0.7 and C-6-0.7 - 55\%.

3. the strengthening effect has decreased from $172 \%$ to $146 \%$ by load-bearing capacity and from $218 \%$ to $55 \%$ by loading of maximum allowed deflection when existing loading was $65-70 \%$ from load-bearing capacity of unstrengthen one.

These obtained features should be taken into account when we design the system of strengthening by RC jacketing applied to real constructions.

\section{References}

1. $\mathrm{Wu}$, Chengqing \& $\mathrm{Li}$, Jun \& $\mathrm{Su}, \mathrm{Yu}$. Development of Ultra-High Performance Concrete Against Blasts (2018)

2. Ekkehard \& Habil, Michael \& Walraven, Joost \& Leutbecher, Torsten \& Fröhlich, Susanne. Ernst \& Sohn GmbH \& Co. KG (2014)

3. K. Sobol, Z. Blikharskyy, N. Petrovska, V. Terlyha. Chemistry \& Chemical Technology. 8 (2014)

4. Ž. Kos, L. Gotal Dmitrović, E. Klimenko. Tehnički glasnik. 11, 4 (2017)

5. J. Selejdak, R. Khmil, Z. Blikharskyy. Matec Web of Conferences. 183 (2018)

6. Y. Blikharskyy, R. Khmil, Z. Blikharskyy. Matec Web of Conferences. 174 (2018)

7. P. Krainskyi, Y. Blikharskyy, R. Khmil, Z. Blikharskyy. Matec Web of Conferences. 183 (2018)

8. Abu-Tair A., S. Rigden, E. Burley, ACI Mat. J. 93, 6 (1996)

9. P. Vegera, R. Vashkevych, Z. Blikharskyy. Matec Web of Conferences. 174 (2018)

10. Sayed A. J. Eng. Sc., 37, 3 (2009)

11. E. Julio, F. Branco, V. Silva. Prog Struct Eng Mat, 9 (2003)

12. A. Meda, G.A. Plizzari, Z. Rinaldi, G. Martinola, Con. Rep., Rehab. and Ret. II, 6 (2009)

13. Y. M. K. Vijaya, G. Siddappa, S. Chandra, IJRET 4 (2015)

14. C. Talbot, M. Pigeon, D. Beaupre, D. Morgan, ACI Mat. J. 91, 7 (1994)

15. D. Stoppenhagen, J. Jirsa, L. Wyllie, ACI Str. J. 92, 11 (1995)

16. S. Sugano, New Zeal. Nat. Soc. for Earthq. Eng. 14,14 (1981)

17. Q. Zhang, Y.V. Mol'kov, Y.M. Sobko, Y.Z. Blikhars'kyi, R.E. Khmil. Materials Science, 50 (6) (2015)

18. National Standard of Ukraine, DBN B.2.6 - 98: 2009, 84 (2011) 